Summer 2006

\title{
Using Global Themes to Reframe the Bioprospecting Debate
}

Jonathan B. Warner

Indiana University School of Law

Follow this and additional works at: https://www.repository.law.indiana.edu/ijgls

Part of the International Law Commons

\section{Recommended Citation}

Warner, Jonathan B. (2006) "Using Global Themes to Reframe the Bioprospecting Debate," Indiana Journal of Global Legal Studies: Vol. 13 : Iss. 2 , Article 13.

Available at: https://www.repository.law.indiana.edu/ijgls/vol13/iss2/13

This Note is brought to you for free and open access by the Law School Journals at Digital Repository @ Maurer Law. It has been accepted for inclusion in Indiana Journal of Global Legal Studies by an authorized editor of Digital Repository @ Maurer Law. For more information, please contact rvaughan@indiana.edu.

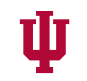

JEROME HALL LAW LIBRARY

INDIANA UNIVERSITY

Maurer School of Law
Bloomington 


\title{
Using Global Themes to Reframe the Bioprospecting Debate
}

\author{
JONATHAN B. WARNER*
}

\begin{abstract}
The objective of this Note is to use global themes and perspectives to aid in reframing the bioprospecting debate. The current state of this debate, its problems, and proposed solutions are reviewed. In looking at the impact of local responses to globalization on bioprospecting themes, I propose that more internationally competitive laws could allow an escape from some of the undesired effects of bioprospecting, while promoting more desired effects. I also suggest, independently, that undesired effects could be avoided and desired effects promoted through methods that seek to recognize the global identity of concerned citizens.
\end{abstract}

\section{INTRODUCTION}

Bioprospecting, or "biopiracy," begins when firms from developed countries, such as multinational corporations based in the United States, interact with aboriginal or indigenous cultures in developing countries. The firms learn the "traditional knowledge" of these cultures, especially as that knowledge is applied to biotechnology. This knowledge is then appropriated by that firm under

*J.D., 2006, Indiana University School of Law-Bloomington. I would like to thank Lisa, Matt, and the rest of my family for their support and encouragement. I would also like to thank Professor Sean Pager and the staff of the Indiana Journal of Global Legal Studies, especially Karen Levy, for their review, comments, expertise, and dedication.

1. See, e.g., Vandana Shiva, Protect or Plunder? Understanding Intellectual Property Rights 49 (2001) ("Biopiracy refers to the use of intellectual property systems to legitimize the exclusive ownership and control over biological resources and biological products and processes that have been used over centuries in non-industrialized cultures."). Dr. Shiva goes on to distinguish bioprospecting as a subclass of biopiracy that offers benefits of sharing, id. at 63-68, but I use the terms synonymously to avoid the negative connotations that accompany the term "biopiracy." $\mathrm{My}$ use of "bioprospecting" also follows from the World Resources Institute's definition of "biodiversity prospecting," id. at 64, as well as other commentators' use on the subject. E.g., Emily Marden, The Neem Tree Patent: International Conflict over the Commodification of Life, 22 B.C. INT'L \& Comp. L. Rev. 279, 279 (1999). 
the developed country's intellectual property laws, to the exclusion of the indigenous cultures from which that knowledge originated.

Some commentators have deemed the current rhetoric in the bioprospecting debate inadequate to generate "grass roots support."- The objective of this Note is to use global themes and perspectives to aid in reframing the bioprospecting debate. In doing so, this Note will first provide a general review of the current rhetoric of this debate, including negative effects of bioprospecting and commonly proposed solutions to these effects. This Note will then apply global themes to the bioprospecting debate and propose a legal approach that attempts to harmonize these themes with many of the underlying issues.

As background, in applying global perspectives to analyze this phenomenon, this Note incorporates an understanding of globalization that includes the movement of goods, knowledge, and technology across international borders. ${ }^{3}$ This understanding is focused upon international competition and local responses to globalization. This understanding also considers whether increased globalization correlates to increased socioeconomic inequality or instead to a reduction of poverty, and what can be done to change the status quo in promotion of "the common good."

Part I of this Note provides a general overview of the phenomenon of bioprospecting, including definitions, scope of the present discussion's use of that term, and examples. Part II reviews commonly accepted effects of bioprospecting, notably neocolonialism and the threat to global biodiversity. It also notes positive effects. Part III briefly summarizes the two most prevalent viewpoints on how to best address the phenomenon of bioprospecting, which consist of developing an international or transnational sui generis system and amending the United States patent code. Then, Part IV attempts to reframe the bioprospecting debate. It analyzes bioprospecting through a global lens, giving emphasis to international competitive efforts, embedded globalization, and the response of concerned citizens. Finally, it proposes a legal solution that attempts to harmonize these global themes with the underlying issues of bioprospecting.

2. See Paul J. Heald, The Rhetoric of Biopiracy, 11 CARDozo J. InT'L \& Comp. L. 519, 520-23 (2003).

3. See International Monetary Fund, Globalization: Threat or Opportunity?-What is Globalization (Apr. 12, 2000), http://www.imf.org/external/np/exr/ib/2000/041200.htm \#II.

4. See Jost Delbrück, Globalization of Law, Politics, and Markets-Implications for Domestic Law-A European Perspective, 1 Ind. J. Global LeGal Stud. 9, 11 (1993). 


\section{The Global Phenomenon of Bioprospecting}

As this section demonstrates, bioprospecting, or biopiracy, ${ }^{5}$ begins when firms from developed countries interact with indigenous cultures in developing countries. The firms learn the "traditional knowledge" of these cultures, and then appropriate that knowledge under the developed country's intellectual property laws.

"Traditional knowledge" is defined by one commentator "by its general characteristics: creation through a long period of time which has been passed down from generation to generation; new knowledge is integrated to the existing, as knowledge is improved; improvement and creation of knowledge is a group effort; and ownership of indigenous knowledge varies between indigenous peoples. ${ }^{\circ 6}$ For example, traditional knowledge that is often sought by nonindigenous entities includes the use of plants as medicine or insecticides; ${ }^{7}$ this knowledge has often existed for generations in the relevant indigenous group before being learned by outside entities. Once outsiders appropriate this knowledge, it is then formatted to fit a particular nation's intellectual property laws. ${ }^{8}$ Firms can then argue for broad international protection of this knowledge, such as protection through the World Trade Organization's (WTO) Trade-Related Aspects of Intellectual Property Rights (TRIPS) agreement. ${ }^{9}$ As suggested by the following three examples, the monopoly protection of patents bars indigenous peoples that have made use of traditional knowledge for generations from freely continuing to use that knowledge. ${ }^{10}$

5. See, e.g., SHiva, supia note 1, at 49; see also Marden, supra note 1, at 279.

6. Miriam Latorre Quinn, Protection for Indigenows Knowledge: An International Law Analysis, 14 St. Thomas L. Rev. 287, 292 (2001). See generally Sarah Harding, Defining Traditional KnowledgeLessons from Cultural Property, 11 CARDozo J. INT'L \& CoMP. L. 511 (2003) (comparing "traditional knowledge" to "cultural property").

7. See Marden, supra note 1, at 283 (discussing the various indigenous uses of the neem tree); see also Quinn, supra note 6, at 290-92 (listing other popular examples).

8. See, e.g., Keith Aoki, Neocolonialism, Anticommons Property, and Biopiracy in the (Not-SoBrave) New World Order of International Intellectual Property Protection, 6 IND. J. GLobal LeGaL STud. 11, 20, 26-27 (1998).

9. Id. at 20; see Gerard Bodeker, Traditional Medical Knouledge, Intellectual Property Rights \& Benefit Sharing, 11 CARDozo J. INT'L \& COMP. L. 785, 790 (2003). The international agreements under which firms claim these broad rights are discussed below in Part III.A.1.

10. See generally Shubha Ghosh, Reflections on the Traditional Knowledge Debate, 11 CARdozo J. INT'L \& COMP. L. 497 (2003) (discussing three basic arguments for and against intellectual property protection of traditional knowledge: the public domain position, the appropriation position, and the moral rights position); Silke von Lewinski, The Protection of Folklore, 11 CARdozo J. INT'L \& Comp. L. 747 (2003) (giving a general overview of some modern issues regarding traditional knowledge). 
The appropriation of traditional knowledge has broad ramifications, especially with regard to copyrights and patents. ${ }^{11}$ However, while the copyrighting of traditional folklore and oral heritages is worth exploring further, this Note's discussion is limited to the patenting of traditional knowledge as that knowledge is applied to biotechnology. ${ }^{12}$ For purposes of this Note, "biotechnology" is understood as defined in the Convention on Biological Diversity (CBD). ${ }^{13}$ The CBD defines biotechnology as "any technological application that uses biological systems, living organisms, or derivates thereof, to make or modify products or processes for specific use."

Three popular examples give reality to the phenomenon of bioprospecting: the neem tree, the turmeric plant, and basmati rice. ${ }^{15}$ Each of these bioresources originates in India, and each has been used for its respective purpose for generations. ${ }^{16}$ In the case of the neem tree, ${ }^{17}$ W.R. Grace and Company recently obtained U.S. patents over several neem-based products. ${ }^{18}$ Because neem-based products are and have been common in India for some time, these patents have become a rallying point against what is viewed as Western imperialism toward Indian culture, although in this particular case there seems to be no risk of

11. See infra Part II.

12. While naturally occurring products are not patentable, modifications thereof are patentable in the United States. See Diamond v. Chak rabarty, 447 U.S. 303 (1980). For present purposes, I am assuming that such patents generally can be acquired legitimately in the country of application. For example, while 35 U.S.C. $\$ 102(\mathrm{f})$ may pose particular difficulties, it is assumed that this statute is and can be legitimately avoided. See the basmati rice example, infra p. 5.

13. E.g., Marden, supra note 1, at 279 n.1.

14. Convention on Biological Diversity art. 2, June 5, 1992, 31 I.L.M. 822.

15. Quinn, supra note 6, at 290-92 (outlining these, among other, examples). See generally Graeme W. Austin, Re-Treating Intellectual Property? The WAI 262 Proceeding and the Heuristics of Intellectual Property Law, 11 Cardozo J. INT'L \& CoMp. L. 333 (2003) (discussing the rights of Maori under Te Tiriti o Waitangi); Christine Toomey, Gene Pirates Bleed Indians for AIDS Cure, Times (London), June 4, 1995 (describing the involvement of multinational corporations in India attempting to collect blood from Indians).

16. Quinn, supra note 6, at 290-91.

17. Neem has been known and utilized by indigenous Indian cultures since the days of Sanskrit and has a variety of local uses, although its uses as a medicine and an insecticide are the most popular. See Marden, supra note 1, at 283.

18. Id. at $283-84$. 
adverse socioeconomic effects on the Indian people. ${ }^{19}$ Examples similar to the neem tree are numerous. ${ }^{20}$

As the case of the turmeric plant demonstrates, not all such patents go legally unchallenged. ${ }^{21}$ In 1996, the Indian Council for Scientific and Industrial Research (CSIR) successfully challenged and overturned two U.S. patents covering a method (long known to people indigenous to India) for administering turmeric to wounds for healing. ${ }^{22}$ The United States Patent and Trademark Office (PTO) ruled the patents were anticipated and obvious when the CSIR demonstrated thirty-two prior written references, some in ancient Sanskrit. ${ }^{23}$

Although the threat of patent invalidation, such as occurred with the turmeric plant,,$^{2+}$ may deter relatively unsophisticated patentees, for more sophisticated entities these threats are most likely hollow..$^{25}$ For example, RiceTec, a Texas-based corporation, ${ }^{26}$ recently obtained a patent on basmati rice-a grain produced in India at a rate of 650,000 tons annually. ${ }^{27}$ Unlike the turmeric patent, however, the basmati rice patent crossbreeds the Indian plant with other

19. Id. at 285-86. But see Shayana Kadidal, Subject-Matter Imperialism? Biodiversity, Foreign Prior Art and the Neem Patent Controversy, 37 IDEA 371, 376-78 (1997) (arguing that W.R. Grace's neem-based patents could drive up seed prices everywhere and deny indigenous Indian companies access to the U.S. market, which could possibly be the largest and most lucrative). Issues of neocolonialism are discussed further in Part II.A.

20. See, e.g., Quinn, supra note 6, at 290-92 (also noting cases involving karela juice, quinoa vegetables, periwinkle plants, ayahuasca plants, and the Maytenus buchananii plant).

21. See, e.g., id. at 290 .

22. Id.; Eliana Torelly de Carvalho, Protection of Traditional Biodiversity-Related Knowledge: Analysis of Proposals for the Adoption of a Sui Generis System, 11 Mo. Envtl. L. \& PoL'y Rev. 38, 65 (2003).

23. De Carvalho, supra note 22, at 65 . As a point of general overview, the United States patent code disallows all patent applications that are deemed either "anticipated" (that is, prior art-e.g., earlier patents or other references that already explain the applicant's desired claims) or "obvious" (that is, the applicant does not genuinely claim anything novel for patenting purposes, or the application simply claims a naturally occurring or existing product). See generally 35 U.S.C. $\$ 101$ (2000). With regard to foreign prior art, the U.S. patent code clearly-and controversiallyrequires the foreign prior art to exist in written form for it to anticipate a claim on a later application. 35 U.S.C. $\S 102$ (b) (2000). For a discussion of extending the reach of U.S. patents into the international arena, see Part III.A.1.

24. See Quinn, supra note 6, at 290.

25. Cf. id. at 290-91 (noting the inability to cancel patents on basmati rice and periwinkle plants, both of which are owned by large U.S. companies).

26. See K.S. Jayaramen, India to challenge basmati rice "invention", NA TuRE, Feb. 19, 1999, at 728.

27. Quinn, supra note 6, at 290. 
varieties. ${ }^{28}$ This creates a novel and nonnatural product for U.S. patent purposes. ${ }^{29}$ Such a product perhaps represents the most threatening means for undermining traditional knowledge as a bar to patentability, as international agreements such as TRIPS may allow the newly patented products to then be enforced against indigenous cultures. ${ }^{30}$

\section{Global Effects of Bioprospecting}

The effects of bioprospecting extend beyond the local communities that were the original holders of the traditional knowledge. Bioprospecting can have a negative financial impact on indigenous peoples, as international agreements allow U.S. patent holders to exercise their monopoly protection against indigenous persons in the United States as well as foreign markets. ${ }^{31}$ As discussed below in Subparts $\mathrm{A}$ and $\mathrm{B}$, the negative impacts of biodiversity can also include threats to cultural identity ${ }^{32}$ and environmental resources. ${ }^{33}$ However, commentators also have noted positive effects of bioprospecting, as addressed in Subpart C. ${ }^{34}$

\section{A. Neocolonialism}

Neocolonialism is intricately linked to bioprospecting. ${ }^{35}$ Typically, corporations from developed nations, usually from the northern hemisphere, under Western ideas of property ownership ${ }^{36}$ and intellectual property laws, ${ }^{37}$ appropriate biodiversity from developing nations. ${ }^{38}$ These corporations act under the

\section{Id.}

29. See, e.g., Diamond v. Chakrabarty, 447 U.S. 303 (1980) (upholding the validity of a patent for a nonnatural, genetically engineered oil-eating bacterium).

30. See Aoki, supra note 8, at 20, 26-27; Kadidal, supra note 19, at 376-78. See also infra Part III.A.1.

31. See Aoki, supra note 8, at 20, 26-27; see also Kadidal, supra note 19, at 376-78.

32. See infra Part II.A.

33. See infra Part II.B.

34. See infra Part II.C.

35. See SHiva, supra note 1, at 49.

36. See Remigius N. Nwabueze, Ethnopharmacology, Patents and the Politics of Plants' Genetic Resources, 11 CARDOzo J. INT'L \& COMP. L. 585, 621 (2003) ("Possessive individualism conceptually defines and identifies an individual by the property he or she possesses. It is a Western concept and provides the theoretical underpinning of patent, copyright, and suigeneris protections. It is epistemologically unsuitable for community or collective property ...." (citations omitted)).

37. See generally 35 U.S.C. $§ 101$ (2000).

38. See supra Part I. 
assumption that it is their natural right to take these resources. ${ }^{39}$ As one commentator notes:

The freedom that transnational corporations are claiming through intellectual property rights protection in the GATT agreement on Trade Related Intellectual Property Rights ... is the freedom that European colonizers have claimed since 1492. Columbus set a precedent when he treated the license to conquer non-European peoples as a natural right of European men. The land titles issued by the pope through European kings and queens were the first patents. ... Eurocentric notions of property and piracy are the bases on which the [intellectual property] laws of the GATT and World Trade Organization... have been framed. When Europeans first colonized the non-European world, they felt it was their duty to "discover and conquer," to "subdue, occupy, and possess[]" ... everything, every society, every culture. The colonies have now been extended to the interior spaces, the "genetic codes" of life-forms from microbes and plants to animals, including humans.... The assumption of empty lands ... is now being expanded to "empty life," seeds and medicinal plants... The same logic is now used to appropriate biodiversity from the original owners and innovators by defining their seeds, medicinal plants, and medical knowledge as nature, as nonscience, and treating the tools of genetic engineering as the yardstick of "improvement." ... At the heart of the GATT treaty and its patent laws is the treatment of biopiracy as a natural right of Western corporations, necessary for the "development" of Third World communities. ${ }^{40}$

This neocolonialism takes advantage of and abuses aboriginal cultures by stripping them of their ability to participate fully in markets available for their knowledge and skills. ${ }^{41}$ For example, W.R. Grace's neem-based patents give it control over all such products in, at least, the U.S. market, potentially denying

39. See Vandana Shiva, Biopiracy: The Plunder of Nature and Knowledce 2-5 (1997).

40. Id.

41. See Kadidal, supra note 19, at 376-78; Marden, supra note 1, at 280. 
indigenous Indian companies what could otherwise be their largest and most lucrative market. ${ }^{42}$ Thus, the indigenous peoples and companies could be prevented from applying their knowledge and skills to the capitalist systems dominating the world economy. ${ }^{+3}$ Further, because of their established economic dominance, the northern nations are able to impose their ideologies into international agreements relatively easily. ${ }^{+4}$ This neocolonialism perpetuates the North-South divide, as typically none of the profits made by the multinational companies return to the states or peoples of origination. ${ }^{45}$

\section{B. Loss of Global Biodiversity}

In addition to the problem of neocolonialism, it is generally agreed that the threat of losing the world's biodiversity is growing. ${ }^{46}$ Biodiversity is important for at least two reasons. ${ }^{47}$ First, it is an "ecological theorem" that ecosystems that are more diverse are less vulnerable to destruction. ${ }^{48}$ Second, the loss of biodiversity means the loss of genetic information. ${ }^{49}$ The loss of genetic information, in turn, may result in the loss of "useful templates"-for example, DNA - that may hold keys to medicinal progress. ${ }^{50}$ Bioprospecting may threaten biodiversity in that it leads to the "overuse" - that is, widespread gathering to the point of depletion-of particular bioresources. ${ }^{51}$

Further, bioprospecting may punish indigenous cultures at the interface with vast regions of biodiversity. ${ }^{52}$ These cultures are open about traditional

42. Kadidal, supra note 19, at 376-78. But see Marden, supra note 1, at 285-86 (discussing the extremely unlikely event that W.R. Grace's neem-based patents will actually affect indigenous Indians either socially or economically).

43. See Shiva, supra note 1 , at 66-68.

44. See, e.g., Amy Chua, World on Fire: How Exporting Free Market Democracy Breeds Ethnic Hatred and Global Instability 232 (2003); Jeffrey P. Kushan, Biodiversity: Opportunities and Obligations, 28 VAND. J. TransNat'L L. 755, 757-58 (1995).

45. E.g., Marden, supra note 1, at 280 . This statement is not true across the board, however. See Heald, supra note 2, at 535.

46. See, e.g., Valuing Local Knowledge (Stephen B. Brush \& Doreen Stabinsky eds., 1996).

47. Clifford S. Russell, Two Propositions About Biodiversity, 28 VAND. J. Transna T'L L. 689, 690 (1995).

48. Id.

49. Id.

50. Id. at 690-91.

51. See Ehsan Masood, Medicinal Plants Threatened by Over-use, NATure, Feb. 13, 1997, at 570.

52. See Shiva, supra note 1 , at 48. 
knowledge of bioresources only to have that knowledge monopolized to their detriment (or at least lack of benefit). ${ }^{53}$ Multinational firms rarely share the profits they gain from bioprospecting. ${ }^{54}$ As will be discussed below, profit sharing with indigenous peoples could provide an economic incentive for them to protect what biodiversity they can. ${ }^{55}$ Such incentives would encourage indigenous persons to engage in preservation without wholly denying bioprospecting efforts. ${ }^{56}$ Hence, those who are most familiar with the relevant ecological systems would be placed in a situation of active preservation to ensure minimal and controlled intrusion on their adjacent ecological systems. ${ }^{57}$

\section{Positive Effects of Bioprospecting}

Despite the serious concerns of neocolonialism and loss of biodiversity, there also may be significant positive effects of bioprospecting. ${ }^{58}$ Bioprospecting allows those who are in the best economic position to disseminate valuable information to do so uninhibited. ${ }^{59}$ For example, as many as four-fifths of all drugs have their basis in natural plant resources. ${ }^{60}$ Hence, this use of broad intellectual property protection may increase the likelihood of finding and distributing medicinal cures. ${ }^{61}$ Such cures could especially improve quality of life for indigenous persons. ${ }^{62}$

53. See Aoki, supra note 8, at 20,26-27; Kadidal, supra note 19, at 376-78.

54. See Marden, supra note 1, at 280. But see Heald, supra note 2, at 535.

55. See Daniel M. Bodansky, The Meaning of Biological Diversity: International Law and the Protection of Biological Diversity, 28 VAND. J. TransNat'L L. 623, 626-27 (1995); Rosemary J. Coombe, The Recognition of Indigenous Peoples' and Community Traditional Knowledge in International Law, 14 St. Thomas L. Rev. 275, 280-82 (2001). See generally Russell, supra note 47 (analyzing benefits of biodiversity, harm from its losses, and solutions to protecting it, including providing economic incentives to local peoples).

56. See Russell, supra note 47, at 692.

57. See id.

58. See generally Heald, supra note 2 (outlining positive effects of bioprospecting, including the potential for finding medicinal cures and protecting biogenetic resources, and negative effects of regulation, including increasing the scope of already broad intellectual property rights and increasing transaction costs and the potential for government corruption).

59. See id. at 531-32.

60. Id.

61. See id.

62. Cf. Russel Lawrence Barsh, Pharmacogenomics and Indigenous Peoples: Real Issues and Actors, 11 CARdozo, J. INt'L \& Comp. L. 365, 366 (2003) (suggesting that the only injustice brought against indigenous persons by bioprospecting is the failure to focus genetic research on the health and survival of indigenous persons themselves). 
In addition, it can be argued that bioprospecting breaks down the NorthSouth divide, which tends to separate developed and undeveloped countries, and establishes incentives to preserve the world's biodiversity. Bioprospecting creates economic incentives for large and wealthy businesses to invest in protecting the world's biodiversity to assure that valuable resources are not lost. ${ }^{63}$ Further, knowing that bioresources in themselves may be valuable to developed nations, southern nations may be able to establish a system of protection for domestic resources. ${ }^{6+}$ This system of protection could dramatically increase southern bargaining power and help dissolve the North-South divide. ${ }^{65}$

\section{Addressing the Global Effects of Bioprospecting}

The vast majority of commentators on bioprospecting seek to find solutions to the abovementioned effects of neocolonialism and loss of global biodiversity. The two most prevalent proposals are creating sui generis systems to operate between governments and the for-profit organizations interested in bioprospecting, and amending U.S. patent law. ${ }^{66}$ As shown below, although neither of these

63. See Heald, supra note 2, at 532-34.

64. See, e.g., Robert P. Merges et al., Intellectual Property in the New Technological AGE 316-17 (3d ed. 2003).

65. See generally Craig Allen Nard, In Defense of Geographic Disparity, 88 Minn. L. Rev. 222, 232-34 (2003) (discussing the compensation agreement reached by Merck, a transnational pharmaceutical company, and INBio, a Costa Rican nonprofit conservation institute).

66. Although these two positions are the most prevalent, they are not the totality of positions available. See generally Keith Aoki, Weeds, Seeds and Deeds: Recent Skirmishes in the Seed Wars, 11 Cardozo J. Int'L \& Comp. L. 247 (2003) (arguing for a "limited commons" approach to address problems presented by intellectual property protection of traditional knowledge); Margo A. Bagley, Patently Unconstitutional: The Geographical Limitation on Prior Art in a Small World, 87 Minn. L. Rev. 679 (2003) (arguing that the geographical limitation of 35 U.S.C. $§ 102(b)$ undermines the basic constitutional authority to grant patents only to actual inventors); David R. Downes, How Intellectual Property Could be a Tool to Protect Traditional Knowledge, 25 Colum. J. EnvtL. L. 253 (2000) (outlining five ways intellectual property rights can be used to protect traditional knowledge); Curtis M. Horton, Protecting Biodiversity and Cultural Diversity Under Intellectual Property Law: Toward a New International System, 10 J. EnvrL. L. \& Liric. 1 (1995) (arguing for an approach utilizing intellectual property law, property law, contract law, and politics to protect traditional knowledge); Robert K. Paterson \& Dennis S. Karjala, Looking Beyond Intellectual Property in Resolving Protection of the Intangible Cultural Heritage of Indigenous Peoples, 11 CARdozo J. INT'L \& CoMP. L. 633 (2003) (arguing that application of trademark law would best serve the interests of indigenous persons while also protecting the modern creative spirit); Gelvina Rodriguez Stevenson, Note, Trade Secrets: The Secret to Protecting Indigenous Ethnobiological (Medicinal) Knowledge, 32 N.Y.U.J. Int'L L. \& PoL. 1119 (2000) (arguing that indigenous persons may find protection from Western intellectual property laws in trade secret law). 
proposed solutions alone may be completely effective, their combined efforts may yield a favorable solution.

\section{A. Sui Generis Systems}

A popular proposal to prevent the negative effects of bioprospecting is the creation of a sui generis system between governments of developing countries and for-profit organizations seeking the bioresources of those countries. ${ }^{67}$ Such systems usually take one of two forms: involvement by intergovernmental agencies or local governments-the approach taken by the WTO, the World Intellectual Property Organization (WIPO), and India-or the promotion of reciprocal, profit-sharing techniques between multinational corporations and the indigenous cultures in question-an approach popularized in Costa Rica. ${ }^{68}$ These systems can be established through contracts, legislation, or an expanded understanding of human rights. ${ }^{69}$ However, practical considerations may result in the long-term failure of these systems. ${ }^{70}$

\section{In General}

Arguments favoring involvement by governmental bodies note several potential benefits, whether they involve intergovernmental agencies, such as the WTO or WIPO, or internal legislative acts, such as those found in India. ${ }^{71}$ These benefits include an emphasis on the commonly held indigenous perspective that communal rights underlie traditional knowledge ${ }^{72}$ and an opportunity for increased access to traditional knowledge. ${ }^{73}$ Other commentators note that even

67. See generally Ong Chui Koon, Intellectual Property Protection of Traditional Medicine and Treatments in Malaysia, in Perspectives on Intellectual Property: Intellectual Property AspeCts of Ethnobiology 153, 172 (Michael Blakeney ed., 1999) ("A sui generis system appears to be the most appropriate scheme for the protection of traditional medicine and other treatments."); De Carvalho, supra note 22, at 59-64 (reviewing some sui generis systems and the CBD).

68. See, e.g., De Carvalho, supra note 22, at 59-61.

69. Part III.A.1-3.

70. See infra Part III.A.4.

71. E.g., Weerawit Weeraworawit, Formulating an International Legal Protection for Genetic Resources, Traditional Knowledge and Folklore: Challenges for the Intellectual Property System, 11 Cardozo J. Int'l \& Comp. L. 769-71 (2003).

72. Id. at 773 .

73. See id. at 776-78 (suggesting that an internationally uniform interpretation of the TRIPS Agreement could aid in the access to and identification of the origin of traditional knowledge and genetic resources). 
where an intergovernmental agreement does not have the force of law in the relevant country, ${ }^{74}$ its "spirit and substance" should be adopted as such. ${ }^{75}$

Arguments favoring sui generis systems that require profit sharing between multinational corporations and indigenous cultures-a method adopted in Costa Rica-also have potential benefits. ${ }^{76}$ As one commentator notes:

|T|here could be a sui generis system derived from this intellectual property system that would fit the needs of the indigenous peoples. ... Pharmaceutical corporations seeking to develop technology based on indigenous knowledge would still benefit... however, the economic benefits and the credit for the source should be awarded justly. In addition, the safeguards on biodiversity[] would further protect the disappearance of plant variety that threaten[s] the world community. It is important after all to recognize that nature and its derivatives are for the community to enjoy, not just for a few who can afford it. ${ }^{77}$

Such a sui generis system could protect worldwide cultures from the loss of global biodiversity. ${ }^{78}$ It also could help eliminate the North-South divide by requiring northern industries to pay adequate compensation to southern peoples for exploitation of the South's genetic resources. ${ }^{79}$ Establishment of these sui generis systems can be through acts of intergovernmental agencies, local "sword and

74. Such as the CBD in the United States. De Carvalho, supra note 22, at 59.

75. Edgar J. Asebey \& Jill D. Kempenaar, Biodiversity Prospecting: Fulfilling the Mandate of the Biodiversity Convention, 28 VAnd. J. Transnat'L L. 703, 748, 754 (1995); see Lee A. Kimball, The Biodiversity Convention: How to Make it Work, 28 VAnd. J. Transnat'L L. 763, 765 (1995); Catherine Tinker, Responsibility for Biological Diversity Compensation Under International Law, 28 VAND. J. Transnat'L L. 777, 780 (1995); W. Robert Ward, Man or Beast: The Convention on Biological Diversity and the Emerging Law of Sustainable Development, 28 VAND. J. TRANSNAT'L L. 823, 827-28 (1995).

76. E.g., Nard, supra note 65, at 232-34. Cf. Shiva, supra note 1, at 64 ("Benefit sharing ... is the equivalent of stealing a loaf of bread and then sharing the crumbs.").

77. Quinn, supra note 6, at 313.

78. See, e.g., Nwabueze, supra note 36, at 625 (discussing the compensation agreement reached by Merck, a transnational pharmaceutical company, and INBio, a Costa Rican nonprofit conservation institute).

79. See, e.g., id. 
shield" legislation-acts that seek to protect local interests while also defeating outside exploitation of those interests ${ }^{80}$ - or government-corporate contracts. ${ }^{81}$

\section{Intergovernmental Agencies}

The WTO and WIPO are leading intergovernmental actors in the intellectual property arena. The WTO is the major international force behind the protection of patent rights beyond the issuing nation's own borders. ${ }^{82}$ The WTO has instituted the TRIPS agreement as a component of its more general international agreement, the General Agreement on Tariffs and Trade (GATT). ${ }^{83}$ The TRIPS agreement has been criticized for its role in perpetuating bioprospecting and its abuses. ${ }^{8+}$ While the WTO recently has sought to review these problems, ${ }^{85}$ TRIPS does not confer rights upon traditional knowledge or genetic resources. ${ }^{86}$ Rather, many of TRIPS's provisions are open to interpretation by the Member States as to the scope of any remedial or preventative nature ${ }^{87}$ As one scholar notes:

The TRIPS Agreement is silent on traditional knowledge, genetic resources, folklore and biodiversity. However, it has certain provisions that could be interpreted in favour of the concept of transfer of technology and access. Article 7 stipulates the objectives of the Agreement that "[t]he protection and enforcement of intellectual property rights should contribute to the promotion of technological innovation and to the transfer and dissemination of technology, to the mutual advantage of producers and users of technological knowledge and in a manner conducive to social and economic welfare, and to a balance of rights and obligations." Article 8 stipulates the principles that include the prevention against

80. See Doris Estelle Long, The Impact of Foreign Investment on Indigenous Culture: An Intellectual Property Perspective, 23 N.C. J. Int'L L. \& Com. Reg. 229, 263 (1998).

81. See id. at 263-79; Rekha Ramani, Note, Market Realities v. Indigenous Equities, 26 BrooklyN J. INT'L L. 1147, 1161-64 (2001). An example from Costa Rica is noted infia at 659-61.

82. See Bodeker, supra note 9 , at 790.

83. See Aoki, supra note 8, at 15-16.

84. See id. at 15-21.

85. See Bodeker, supra note 9, at 790-93; see also The WTO's Website, Article 27.3b. Traditional Knowledge, Biodiversity, http://www.wto.org/english/tratop_e/trips_e/art27_3b_e.htm (last visited Oct. 15, 2005) [hereinafter WTO Website].

86. Weeraworawit, supra note 71 , at 777.

87. See id. at 776-77. 
the abuse of intellectual property rights or restrictive practices. These provisions are broad and subjected to ... interpretation by the Member states. They provide the safeguard, but not the protection for traditional knowledge, genetic resources, or folklore directly. The same thing could be said about Article 27.2 on the exclusion from patentability on the ground of public order or morality, including prejudice to the environment. They could be used to prevent ... unfair or abusive exploitation of genetic resources, but they do not confer legal protection to traditional knowledge or genetic resources. Article 67 deals with technical cooperation from the developed countries to the developing and least developed countries. It also refers to assistance in the prevention against abuse. ${ }^{88}$

The allowance for Member States to adopt their own remedial or preventative solution is more explicitly acknowledged in article 27.3(b) of TRIPS, which allows "for the protection of plant varieties either by patents, by an effective sui generis system or by any combination thereof." ${ }^{89}$ This specific article is currently being considered by the WTO for expansion or harmonization with the CBD. ${ }^{90}$ As sui generis systems are uniquely developed by a country or region according to that country's or region's needs, ${ }^{91}$ the TRIPS component of GATT authorizes countries or regions to apply their individual solutions to bioprospecting problems; however, the general view under TRIPS is that traditional knowledge is a part of a "global commons available for exploitation by all." 2

WIPO, a specialized agency of the United Nations, also has recently visited the bioprospecting issue. ${ }^{93}$ However, the results of WIPO's recent discussions on the issue are inconclusive: On the one hand, WIPO's consideration of the bioprospecting issue is a clear indication of the issue's importance; on the other hand, it is also clear that many countries remain unconvinced as to whether, or

88. Id.

89. Bodeker, supra note 9, at 790 (quoting art. 27.3(b)).

90. See id. at 791-92; see also WTO Website, stupra note 85.

91. Bodeker, supra note 9 , at 790 .

92. Id.

93. See Weeraworawit, supra note 71, at 770; see also The WIPO's Website, Intergovernmental Committee on Intellectual Property and Genetic Resources, Traditional Knowledge and Folklore 2 (2005), http:/www.wipo.int/edocs/mdocs/tk/en/wipo_grtkf_ic_8/wipo_grtkf_ic_8_decisions.pdf [hereinafter WIPO Website]. 
how, to change the international patent regime. ${ }^{9+}$ The leading proposal for addressing bioprospecting under the auspices of WIPO seems likely to be a variation of the Model Provisions for National Laws on the Protection of Expressions of Folklore Against Illicit Exploitation and Other Prejudicial Actions (Model Provisions). ${ }^{95}$ Although the Model Provisions are based on the protection of traditional folklore from foreign copyrights, the framework may be applicable to bioprospecting. ${ }^{96}$ However, the criminal and civil penalties under the Model Provisions are, like the laws that allow for bioprospecting to begin with, Western in origin, perhaps perpetuating North-South issues. ${ }^{97}$ Specifically, the folklore protection provided by the Model Provisions is based on an adaptation of Western copyright law - a law which itself is accused by indigenous persons as being the source of the problems. ${ }^{98}$ This adaptation shifts ownership in the folklore from a creating individual to an individual authorized to license the use of the folk lore. ${ }^{99}$ However, this solution still misses the communal property mindset pervasive among indigenous cultures in these matters. ${ }^{100}$

\section{Local Legislation}

India and Costa Rica have taken different approaches to internal sui generis responses and solutions. India has enacted several "sword-and-shield" attempts to curb bioprospecting efforts and protect its traditional knowledge, while Costa Rica has sought a profit-sharing technique with bioprospecting companies. One of India's legislative acts punishes those who apply for a patent in India that is based on Indian bioresources with up to five years in prison and up to a $\$ 30,000$ fine. ${ }^{101}$ Because indigenous persons are unlikely to seek such a patent, the broad language in the law seems unlikely to ever apply to them. Similar measures have

94. See Weeraworawit, supra note 71, at 778; see also WIPO Website, supra note 93, at 2.

95. See Nwabueze, supra note 36, at 620; United Nations Educational, Scientific and Cultural Organization, Model Provisions for National Laus on the Protection of Expressions of Folklore Against Illicit Exploitation and Other Prejudicial Actions (1985), available at http://www.wipo.int/th/en/ documents/pdf/1982-folklore-model-provisions.pdf [hereinafter Model Provisions].

96. Nwabueze, supra note 36 , at 620.

97. See id. at 620-21. With regard to the Model Provisions' criminal and civil penalties, these are left open for precise definition by an enacting country. See Model Provisions, supra note 95, II 20 , $25, \S \S 6-8$.

98. Nwabueze, supra note 36 , at 621.

99. See id.

100. See id.

101. K.S. Jayaraman, India Drafts Latu to Protect Bioresources, NATUre, Nov. 13, 1997, at 108. 
been enacted in other countries. ${ }^{102}$ Other Indian legislation is purely defensive. ${ }^{103}$ For example, India recently took affirmative steps toward the creation of a digital library of traditional knowledge in an attempt to preempt applicants for U.S. patents by creating a published foreign use, undermining any assertions that a patent application meets the United States' novelty requirement. ${ }^{10+}$ Some of this information is being published in up to six languages. ${ }^{105}$ However, while such databases may operate effectively to preempt the patentability of certain subject matter, ${ }^{106}$ they may ultimately be nothing more than a fast track to biopiracy for more sophisticated firms capable of making technical alterations to recorded information for purposes of patentability. ${ }^{107}$

The Costa Rican sui generis system is a compensation-based model, unlike the "sword-and-shield" approach taken in India. A popular example is the 1991 agreement between the Instituto Nacional de Biodiversidad (INBio), a private, nonprofit Costa Rican conservation organization, and Merck, a U.S.-based multinational pharmaceutical company. ${ }^{108}$ Under this agreement:

INBio initially supplied Merck with ten thousand biosamples or extracts from wild plants, insects and micro-organisms for a consideration of 1.135 million dollars (U.S.). One million dollars was paid up-front in cash, while $\$ 135,000$ represented the value of scientific equipment supplied to INBio by Merck. Under the contract INBio would, in addition, be paid [a] certain percentage of the royalties resulting from any commercialization of the re-

102. See, e.g., De Carvalho, supra note 22, at 44-47 (discussing measures taken in Costa Rica, Brazil, and Australia). See generally Justice Ronald Sackville, Legal Protection of Indigenous Culture in Australia, 11 Cardozo J. INT'L \& Comp. L. 711 (2003) (discussing the slow but positive changes in Australian law favoring indigenous heritage).

103. See India: CSIR Chief Stress on Non-Patent Database, Bus. Line, Sept. 23, 2000.

104. See India: CSIR Files 200 Patents Abroad, Bus. Line, Nov. 3, 2000. The U.S.'s published foreign-use bar is codified at 35 U.S.C. $\$ 102$ (b) (2000).

105. India to Publish Ayruvedic Tiacts on the Internet in Six Languages, Nutraceuticals Int'L, May 1, 2002.

106. See generally Ikechi Mgbeoji, Patents and Traditional Knowledge of the Uses of Plants: Is a Communal Patent Regime Part of the Solution to the Scourge of Bio Piracy?, 9 IND. J. GLobal Legal STud. 163 (2001) (arguing for the creation of national registries of traditional knowledge).

107. See Bodeker, supra note 9, at 803-05. See also the basmati rice example, supra at 649-50.

108. See Nwabueze, supra note 36 , at 625 ; see also Nard, supra note 65 , at 232-34. 
sources it supplied. The money realized by INBio would be applied to conservation efforts, training and capacity-building. ${ }^{109}$

Such agreements allow for at least some flow of proceeds from products developed through bioprospecting to return to the country of origin.

Sui generis systems may find moral justification in a human rights analysis. ${ }^{110}$ As one commentator notes, "protecting traditional knowledge cannot be achieved without also upholding the individual and collective human rights of traditional knowledge holders and their communities." "II This expansion of human rights could naturally lead to a system of reciprocal compensation between the profiting firm and either the indigenous peoples or their host country. ${ }^{112}$ Expansion of human rights may also lead to a long-term resolution to the bioprospecting problem, but this expanded understanding is unlikely to occur on a sufficiently broad scale in a relatively short time frame. ${ }^{113}$

\section{Problems with Sui Generis Systems}

Sui generis systems between local governments and multinational, forprofit organizations generally cannot be implemented as currently proposed without concern for their long-term stability. In some cases, proposed resolution of issues may not be truly obligatory. ${ }^{114}$ In other cases, the sui genéris system may not be truly effective. ${ }^{115}$ For example, a critical concern underlying many international or transnational sui generis systems is identifying a court in which these

109. Nwabueze, supra note 36, at 625.

110. See Graham Dutfield, Protecting and Revitalizing Traditional Ecological Knowledge: Intellectual Property Rights and Community Knowledge Databases in India, in Intellectual Property AsPects of Ethnobiology 101, 121 (Michael Blakeney ed., 1999). See generally Rosemary J. Coombe, Intellectual Property, Human Rights \& Sovereignty: New Dilemmas in International Law Posed by the Recognition of Indigenous Knowledge and the Conservation of Biodiversity, 6 IND. J. GLOBAL LECAL Stud. 59 (1998) (analyzing intellectual property rights from an international human rights view).

111. Dutfield, supra note 110, at 121.

112. See Naomi Roht-Arriaza, Of Seeds and Shamans: The Appropriation of the Scientific and Technical Knowledge of Indigenous and Local Communities, 17 MrCH. J. INT'L L. 919, 951-53 (1996). The InBio-Merck agreement is an example of a firm-country agreement, although that agreement was based on environmental protection rather than human rights.

113. See Heald, supra note 2, at 522-27.

114. See De Carvalho, supra note 22, at 59.

115. See Chris Farrands, The Globalization of Knowledge and the Politics of Global Intellectual Property: Power, Governance and Technology, in Globalization: Theory and Practice 175, 184 (Eleonore Kofman \& Gillian Youngs eds., 1996). 
systems can be enforced. ${ }^{116}$ However, even where obligatory enforcement procedures may be clear, they may still prove questionable in their effectiveness. ${ }^{117}$ For example, WTO arbitration under TRIPS, while obligatory, is somewhat dependent on the bargaining power of the countries in question. ${ }^{118}$ If the two parties to a dispute are the United States and Madagascar, ${ }^{119}$ for example, bargaining power is unlikely to be equal, and the U.S.-based corporations that are the source of the dispute may be able to economically justify a breach of contract or other failure to adhere to Madagascar's demands. ${ }^{120}$ So long as this disparity in bargaining power exists, a permanent effective solution is unlikely. ${ }^{121}$

In addition, although agreements such as the INBio-Merck agreement allow for some of the proceeds to return to the country of origin, it is likely that these proceeds are nominal compared to the bioprospecting company's profits. ${ }^{122}$ Also, such agreements do not necessarily address the exclusion of indigenous persons from capitalist markets.

\section{B. Amending U.S. Patent Law-The Long Term Solution}

The primary policy of U.S. patent law is to protect the inventor of a "new and useful process, machine, manufacture, or composition of matter"; ${ }^{123}$ thus, patents such as the basmati rice patent are squarely within the policies of U.S.

\section{See id.}

117. See A. Claire Cutler, Private International Regimes and Interfirm Cooperation, in The Emergence of Private Authority in Global Governance 23, 31 (Rodney Bruce Hall \& Thomas J. Biersteker eds., 2002); see also Ronnie D. Lipschutz \& Cathleen Fogel, "Regulation for the Rest of Us?": Global Civil Society and the Privatization of Transnational Regulation, in THE EMERGence of Private Authority in Global Governance 115, 116 (Rodney Bruce Hall \& Thomas J. Biersteker eds., 2002) (noting other systemic problems with WTO arbitration).

118. See Cutler, supra note 117 , at 31 .

119. These two countries were not chosen arbitrarily. See generally Quinn, supra note 6, at 291 (discussing the Periwinkle case).

120. See Cutler, supra note 117, at 31.

121. Srividhya Ragavan, Protection of Traditional Knowledge, 2 Minn. Intell. Prop. Rev. I, 2 (2001) (" $[\mathrm{I}] \mathrm{n}$ order for traditional knowledge to be protected effectively either within the prevailing intellectual property regime or by a separate regime, the bargaining power of developing countries must be strengthened."); see also Michael H. Davis, Some Realism About Indigenism, 11 CARdozo J. INt'L \& Comp. L. 815, 829-30 (2003) (arguing for the need to establish a system of competitive wealth).

122. Cf. SHIVA, supra note 1 , at 64 .

123. 35 U.S.C. $\$ 101$ (2000). 
patent law. ${ }^{12+}$ In response to this broad policy, many commentators suggest amending U.S. patent law to reflect sensitivity toward developing nations and peoples in cases of bioprospecting. ${ }^{125}$ To effectuate this increased sensitivity, the United States Congress or courts could adopt moral rights, ${ }^{126}$ or Congress could recognize unpublished foreign prior use as a bar to patentability. ${ }^{127} \mathrm{Also}$, Congress could seek to increase international harmonization among intellectual property rights, for example by increasing conformity to the CBD. ${ }^{128}$ Finally, Congress could propose legislation to encourage INBio-Merck-type agreements, increasing benefits sharing in an attempt to make developing countries willing partners in utilizing bioresources. ${ }^{129}$ Such legislation, perhaps, could create an exception to patentability for any traditional-knowledge-based patents-such as W.R. Grace's neem-based patents-that are secured without such an agreement. $^{130}$

124. See, e.g., Diamond v. Chakrabarty, 447 U.S. 303 (1980).

125. See generally Michael R. Taylor \& Jerry Cayford, American Patent Policy, Biotechnology, and African Agriculture: The Case for Policy Change, 17 HARv. J.L. \& TЕсH. 321, 399 (2004) ("Based on our analysis, the United States could make changes in both its domestic and foreign policies that would improve developing-country access to the patented tools of biotechnology while preserving the core invention incentives of the patent system."); Traci L. McClellan, Note, The Role of International Law in Protecting the Traditional Knowledge and Plant Life of Indigenous Peoples, 19 W1s. INT'L L.J. 249, 265-66 (2001) ("However, indigenous leaders and advocates for indigenous peoples have called on the PTO to change its rules and develop a system to prevent the patenting of indigenous peoples' intellectual property rights in the future. This type of action should be taken by all nation-states who have yet to draft laws and policies putting their country in step with current international law.").

126. E.g., Leanne M. Fecteau, Note, The Ayahuasca Patent Revocation: Raising Questions About Current U.S. Patent Policy, 21 B.C. ThiRd World L.J. 69, 87-95 (2001) (discussing, inter alia, legislative and common law expansion of the utility requirement to include the "good morals of society" (quoting Lowell v. Lewis, 15 F. Cas. 1018, 1019 (Story, Circuit Justice, C.C.D. Mass. 1817) (No. 8,568))). Moral rights are a popular requisite for some intellectual property protection outside of the United States. See Merces, supra note 64, at 443.

127. E.g., Fecteau, supra note 126, at 95-98 (arguing that Congress ought to reconsider 35 U.S.C. $\S 102$, the patent novelty requirement, so that the statute's geographic limitation is eliminated and foreign prior use in the form of traditional knowledge is recognized as prior art). See generally William LaMarca, Reevaluating the Geographical Limitation of 35 U.S.C. $\$ 102(b)$; Policies Considered, 22 U. Dayton L. Rev. 25 (1996) (discussing the historical justifications of $\$ 102(\mathrm{~b})$ ).

128. See, e.g., Fecteau, supra note 126, at 99-102 (arguing that TRIPS should be harmonized with the CBD by putting forth an amendment that seeks to protect communal intellectual property).

129. See, e.g., Russell, supra note 47, at 692 (discussing how agreements between developing countries and bioprospecting firms create incentives that encourage biological preservation).

130. Cf. Fecteau, supra note 126, at 95-98 (discussing reasons for amending the patent novelty requirement). 
Each of these proposals raises some concerns. The United States has actively chosen to not adopt moral rights or other policies common outside the United States and reflected in international systems, such as a first-to-file system. ${ }^{131}$ Also, altering the policies of the United States may result in losing the positive effects that bioprospecting stands to offer, especially if amendments to the U.S. patent code change longstanding U.S. policies too drastically. ${ }^{132}$

While an amendment to the U.S. patent code could be a stable long-term solution, any amendment likely to drastically change longstanding U.S. policies would require a lengthy amount of time to gain approval. ${ }^{133}$ As such, this solution is untenable in the short term. ${ }^{134}$ So long as the United States and other northern nations are economically ahead of the rest of the world in their intellectual property law systems, ${ }^{135}$ these nations are unlikely to make changes that would negatively affect their competitive advantage. ${ }^{136}$

\section{Local Responses to Globalization}

The current rhetoric in the bioprospecting debate is inadequate to accomplish the goals of many commentators on this subject, most notably because of the problems with sui generis systems and the lack of appeal to either Congress or U.S.-based businesses in amending U.S. patent law. ${ }^{137}$ While sui generis systems are unlikely to be effective permanent solutions, ${ }^{138}$ they may be sufficient until amendments to the U.S. patent system gain favor. ${ }^{139}$ Still, it is conceded that

131. See Merces, supra note 64, at 291-92.

132. Cf. Kushan, supra note 44, at 757-58 (noting that imposition of intellectual property policies by the developed nations onto the developing nations is comparable to neocolonialism). See also J.H. Reichman, Enforcing the Enforcement Procedures of the TRIPS Agreement, 37 V A. J. INr'L L. 335, 33940 (1997) ("Few things touch the delicate nerve of national sovereignty more than the autonomous capacity of states to administer their domestic laws in conformity with their own legal philosophies. States that have only recently achieved economic and political independence will especially resent other, more powerful states sitting in judgment of the way they exercise their sovereignty ....").

133. See generally Taylor \& Cayford, supra note 125, at 382 (discussing the slow but promising rise in awareness among policymakers of the need for change in U.S. patent policies).

134. Cf. id. at 399.

135. See, e.g., ChUA, supra note 44 , at 232 ; Kushan, supra note 44 , at 757-58.

136. See Heald, supra note 2 , at 543.

137. See generally id. (discussing the need to change the rhetoric surrounding issues of bioprospecting).

138. See supra Part III.A.4.

139. See generally Taylor \& Cay ford, supra note 125, at 283-84 (discussing the slow but promising rise in awareness among policymakers of the need for change in U.S. patent policies). 
U.S. patent policies are not without positive effects that outweigh the desire to adjust for bioprospecting. ${ }^{1+0}$ As explained below, by considering dominant global themes ${ }^{1+1}$ with the bioprospecting debate, it may be possible to reframe the proposed sui-generis-amendment solutions in such a manner as to preserve the positive effects of current U.S. patent policies while addressing the need to protect traditional knowledge. Specifically, focusing resolution of the bioprospecting debate on increased international competition ${ }^{142}$ and the response of globally concerned local citizens ${ }^{1+3}$ shows how possible resolution of the bioprospecting debate can be achieved in a way likely to garner grass-roots support. ${ }^{1+4}$

\section{A. International Competition}

Bioprospecting is naturally implicated by an understanding of globalization that involves the increasing movement of goods, knowledge, and technology across international borders. ${ }^{1+5}$ As has been demonstrated, bioprospecting is the movement of traditional knowledge from the developing country as a point of origin to the developed country as a point of production. ${ }^{1+6}$ Goods are then shipped back across borders in reverse order, from developed country to developing country and others in the global marketplace as rich multinational corporations increase profits at the expense of undeveloped, indigenous cultures. ${ }^{147}$

When viewed through this global lens, the rise of bioprospecting activities creates concern analogous to a "race-to-the-bottom" for control over indigenous knowledge. ${ }^{148}$ As one commentator notes:

140. See generally Heald, supra note 2 (outlining positive effects of bioprospecting, including the potential for finding medicinal cures and protecting biogenetic resources, and negative effects of regulation, including increasing the scope of already broad IP rights and increasing transaction costs and the potential for government corruption).

141. See generally David Held \& Anthony McGrew, The Global Transformations Reader (2d ed. 2003) (collecting works into five common themes of globalization: the reconfiguration of power and authority of states, the loss of a singular cultural identity, the dominance of the world marketplace, the perpetuation of inequality among nations, and the emergence of new extranational entities).

142. Supra Part IV.A.

143. Supra Part IV.B.

144. See Heald supra note 2, at 543.

145. See International Monetary Fund, Globalization: Threat or Opportunity? (Apr. 12, 2000), http://www.imf.org/external/np/exr/ib/2000/041200.htm\#II.

146. See supra Part I.

147. Id.

148. Alfred C. Aman, Jr., Globalization and Federalism: Governance at the Domestic Level, in Coping with Globalization 94, 98-99 (Aseem Prakash \& Jeffrey A. Hart eds., 2000). 
Globalization encourages increasingly intense international competition among nations, states and cities to attract and keep industries that they believe can create economic growth in their areas. Though the location of a plant or manufacturing operation turns on numerous, primarily cost-related factors, low taxes[] and the imposition of minimal regulatory costs on industries located in these jurisdictions usually constitute important elements of a jurisdiction's strategy to attract industry and jobs to a particular locale. ${ }^{149}$

Hence, as the wealth of the bioprospecting industry increases, the likely regulation of this industry decreases. ${ }^{150}$

Rather than relying solely on the sui-generis-amendment solutions to the bioprospecting debate, developing countries may find that the most protective measure would be the adoption of an intellectual property system competitive with that of the United States. ${ }^{151}$ For example, the developing countries at issue could seek to establish laws that allow for a broader range of patents for individuals, including those sought on traditional-knowledge-based products. ${ }^{152} \mathrm{How}$ ever, as developing countries often view such property as community-based property, ${ }^{153}$ these new laws could create a localized dual-rights system. The patent would be recognized as valid in the developing country-and therefore also valid abroad under TRIPS ${ }^{154}$ - but the patent's monopolistic rights would be unenforceable within the developing country, which is not likely to be a bioprospecting company's target market. ${ }^{155}$ In other words, the bioprospecting firm would get a patent in the country where the knowledge on which the patent is

149. Id.

150. See id.

151. Cf. id.

152. See generally Michael W. Smith, Bringing Developing Countries' Intellectual Property Laws to TRIPS Standards: Hurdles and Pitfalls Facing Vietnam's Efforts to Normalize an Intellectual Property Regime, 31 Case W. Res. J. INT'L L. 211 (1999) (discussing the economic, legal, and social issues involved when a non-Western, developing nation adopts Western-style intellectual property protection to encourage foreign investment and involvement in world trade). The United States' broad policy for patents available on an individual or corporate basis was announced in Diamond v. Chak rabarty, 447 U.S. 303 (1980).

153. Cf. Aoki, supra note 8 , at 26-28 (discussing the difficulty in shifting the mindset of indigenous people from a communal-property understanding to a personal-rights understanding).

154. See id. at 20, 26-27.

155. See id.; Kadidal, supra note 19, at 376-78. 
based originated, but this patent would only be enforceable in the international arena. ${ }^{156}$ This system would maintain the developing nation's internal market over the traditional knowledge, ${ }^{157}$ while at the same time maintaining bioprospecting companies' incentives to gather and distribute potentially lifesaving medicines. ${ }^{158}$ Such a system would also be to the economic advantage of both the developing countries and the bioprospecting companies. Developing countries already have the cost-related advantages of location and access to traditional resources and bioresources, ${ }^{159}$ and adapting competitive intellectual property laws could encourage multinational corporations to establish regional locations to take advantage of this protection, location, and access. ${ }^{160}$

This legal proposal directly addresses the commonly identified problems and benefits of bioprospecting. This proposed system may present ideological conflicts, at least insofar as the developing country is acquiescing to northern demands of intellectual property recognition. ${ }^{161}$ Nevertheless, these conflicts could be mitigated by the fact that the legal change stems from the country of the traditional knowledge's origin. ${ }^{162}$ In addition, these conflicts could be mitigated by requiring the patent to be unenforceable in the jurisdiction where the traditional

156. Notably, this solution amounts to a legal endorsement of W.R. Grace's actions regarding the neem patent, since W.R. Grace has elected to develop its neem products and research in India and not to enforce its otherwise internationally valid patent within India. See Marden, stpra note 1, at 285. As noted by the W.R. Grace example, this solution presents a minimal risk of adverse economic impact against indigenous persons and instead presents a real likelihood of socioeconomic gain. See id. But see Kadidal, supra note 19, at 376-78. Hence, this solution also presents a level of concession to the likelihood that bioprospecting will continue to be permitted at least in Western nations.

157. Cf. Aoki, supra note 8, at 20, 26-27; Kadidal, supra note 19, at 376-78 (both authors noting the targeting of the U.S. market over the indigenous markets by bioprospecting companies).

158. See Heald, supra note 2, at 531 ("Hundreds of important and efficacious drugs have already been developed from plants found in developing countries. In fact, four-fifths of all drugs have their basis in natural plant resources.").

159. See SHiva, supra note 1 , at 48.

160. See Aman, supra note 148, at 98-99.

161. See Kushan, supra note 44, at 757-58 (“Southern countries argued that strong intellectual property rights would create instruments that would be used by Northern companies to hinder the flow of technology into Southern markets.").

162. See Angela R. Riley, "Straight Stealing": Towards an Indigenous System of Cultural Property Protection, 80 W ASH. L. Rev. 69, 131 (2005) ("The development of sui generis systems would allow indigenous peoples ... to finally control the integrity, disposition, and appropriation of their sacred knowledge. Thus ... this proposal merely puts indigenous groups on the same footing as other citizens."). 
knowledge behind the patent originates. ${ }^{163}$ Despite this localized nonenforceability, bioprospecting firms could still find these patents favorable because of the recognition of the patent's validity by the developing country. This, in turn, would be a guarantee that the developing country would not litigate or challenge that patent's validity in either that country or in another country that enforces the patent. ${ }^{16 t}$ This competitive legal system would also allow the benefits of bioprospecting, such as finding and disseminating medicinal advances, ${ }^{165}$ to be retained. At the same time, the North-South divide would be attacked since the multinational firms would be employing local citizens and paying local taxes rather than further feeding a developed nation. ${ }^{166}$ Loss of global biodiversity could also be mitigated, as genetic information would be more readily available to companies that can preserve that information, ${ }^{167}$ and information not yet preserved could be guarded by local groups. ${ }^{168}$ Such a system would guarantee the local protection of traditional knowledge in places where the knowledge originated, since it is the host country that is initiating the legal change. ${ }^{169}$

Increased international competition also emphasizes the important role nonU.S. economies can have on the global marketplace. ${ }^{170}$ Underlying this role is the decentralization of the private sector-increasing globalization results in decreased centralization. ${ }^{71}$ This decentralization creates "horizontal forces" between multinational entities and nations. ${ }^{172}$ By diversifying location and protective legal systems, no one national system can regulate the multinational entity. ${ }^{173}$ Thus, competitive systems of protection are likely to encourage the local establishment of multinational entities. ${ }^{174}$ Additionally, the increase in competitive

163. Cf. Reichman, supra note 132 , at $339-40$ ("Few things touch the delicate nerve of national sovereignty more than the autonomous capacity of states to administer their domestic laws in conformity with their own legal philosophies.").

164. See the turmeric plant example, supra at 648-49.

165. See Heald, supra note 2, at 531-32.

166. See Marden, supra note 1 , at 280.

167. See Russell, supra note 47, at 689-90,692.

168. See, e.g., Bodansky, supra note 55, at 626-27; Coombe, supra note 55, at 280-82.

169. Cf. Riley, supra note 162, at 118 ("Indeed, it is frustrating when laws exist to protect traditional knowledge, but they cannot be enforced in the individualized countries where most of the commercial producers and consumers of indigenous cultural property actually live.").

170. See Aman, supra note 148, at 100.

171. See Alan M. Rugman \& Alain Verbeke, Environmental Regulations and the Global Strategies of Multinational Enterprises, in Coping with Globalization, supra note 148, at 77, 78.

172. See Aman, supra note 148 , at 100-01.

173. See id. at 101.

174. See id. at 99. 
intellectual property laws in the developing world would strengthen the bargaining power of the involved developing nations. ${ }^{1 / 5}$

\section{B. Embedded Globalization and the Response of Concerned Citizens}

Globalization also emphasizes the increasingly important role of nonstate actors. ${ }^{176}$ Perhaps most significant is the effect globalization may have on local citizens. ${ }^{177}$ As has been noted:

Global citizenship involves multiple identities and the ability of citizens to differentiate among the various roles that different levels of government perform. At the same time, built into these multiple identities are often conflicting and conflicted responses to certain issues. What might further one's local interest might harm the global competitiveness of the entities that contribute to the economic health of an area or region. ${ }^{178}$

In this sense, then, globalization itself is "embedded" into a domestic culture and individuals. ${ }^{179}$

The multiple identities experienced by a global citizen create global concerns and prompt global responses. ${ }^{180}$ Indeed, in this age, like no other, globally concerned citizens can participate on the world stage. ${ }^{181}$ For example, the Center for International Environmental Law in Washington, D.C. filed a petition for

175. Cf. Ragavan, supra note 121, at 2 (“II]n order for traditional knowledge to be protected effectively either within the prevailing intellectual property regime or by a separate regime, the bargaining power of developing countries must be strengthened.").

176. See generally Alfred C. Aman, Jr., The Democracy Deficit: Taming Globalization Through Law Reform (2004) (arguing that the future of modern democracies depends on the ability of citizens to affect global policies).

177. See Aman, supra note 148, at 101.

178. Id.

179. See Aman, supra note 176, at x ("[G]lobalization is ... embedded in our domestic institutions, both public and private.").

180. See Aman, supra note 148, at 101; Charles R. McManis, Intellectual Property, Genetic Resources and Traditional Knowledge Protection: Thinking Globally, Acting Locally, 11 Cardozo J. INT'L \& Comp. L. 547, 565-76 (2003).

181. See Thomas L. Friedman, The Lexus and the Olive Tree 13 (1999). 
reexamination on an issued patent covering products of Ayahuasca. ${ }^{182}$ As a result of this petition, the issued patent was reversed. ${ }^{183}$ Another group of pro bono lawyers based in Washington, D.C. also recently challenged the validity of certain patents that incorporate indigenous Peruvian medicines. ${ }^{184}$

As the above examples demonstrate, focusing resolution of the bioprospecting debate on the response of globally concerned local citizens shows how U.S. patents can be affected, increasing the economic incentive for bioprospecting companies that are seeking patent protection to take added measures to ensure patent validity. This response of consumers goes beyond the mere use of consumer power to protest. ${ }^{185}$ The economic incentive for multinational corporations to adhere to the laws of developing nations, whether those laws represent sui generis systems or internationally competitive laws, also can be established as the response of globally concerned citizens directly affects bioprospecting corporations. ${ }^{186}$

\section{Conclusion}

The bioprospecting debate presents a controversy that, at its extremes, involves the conflicting views and interests of indigenous peoples and multinational corporations. ${ }^{187}$ As one commentator notes, "[o]nly when indigenous peoples... and ... their cultural world views, customary laws, and ecological practices are recognized as fundamental contributions to resolving local social justice concerns will we be engaged in anything we can genuinely call a dialogue." 188

The current rhetoric of this debate fails to conceptualize the issues of bioprospecting in a manner that will generate grass-roots support. Shifting this de-

182. Glenn M. Wiser, U.S. Patent Office Rejects Patent on Indigenous Medicinal Plant, 15 Envth. Compliance \& Litic. Strategy 5, 5 (2000).

183. Id. It is notable that the PTO reversed the issuance of the patent on the narrowest grounds possible. Id. The patent was founded on a claim that the plant's flowers were novel in their color; the PTO reversed, finding that samples of the plant contained at the Field Museum of Chicago were indistinguishable in flower color from those claimed in the patent application, thereby making the specimens known and available in the United States more than one year prior to the patent application. Id. at 6; see also 35 U.S.C. § 102(b) (2000).

184. Alicia Upano, D.C. Team Gets to the Root of the Problem, Legal Times, Jan. 12, 2004, http:// www.piipa.org/Upanol 1-12-04.pdf.

185. See Aman, supra note 176, at 179 (discussing this highly limited form of power).

186. Cf. Cutler, supra note 117 , at 31 (discussing corporate use of economically efficient breach of contract).

187. See Quinn, supra note 6, at 289.

188. Coombe, supra note 55, at 284-85. 
bate's focus through the lens of globalization emphasizes the role non-U.S. economies and nonstate actors can have on the global economy and the global culture. In this manner, sensitivity toward developing economies and indigenous persons can be accounted for through an internationally competitive intellectual property legal system adopted by developing countries. This proposal addresses the negative effects of bioprospecting while also retaining the positive effects. With the use of embedded globalization and competitive international legal systems, the status quo can be changed in promotion of the common good, and globalization can help to reduce poverty and inequality. 
